\title{
Maturation and physiological quality of IAC-863 Rangpur lime seeds
}

\author{
Marília Morelli(B), Fernando Alves de Azevedo' (10), \\ Patrícia Marluci da Conceição2(iD, Ana Júlia Borim de Souza3 ${ }^{3}$ \\ 'Sylvio Moreira Citriculture Center, Agronomic Institute, Cordeirópolis, Brazil \\ ${ }^{2}$ Federal University of São Carlos, Araras, Brazil \\ ${ }^{3}$ São Paulo State University, Bauru, Brazil \\ *Corresponding author, e-mail: marilia_morelli@hotmail.com
}

\begin{abstract}
There is a growing demand for high quality seeds to obtain citrus rootstocks. Normative Instruction 48 (MAPA) of September 24,2013 , requires minimum of $50 \%$ germination for the marketing of citrus seeds. Harvest season is one of the stages of seed production with great importance to ensure quality, which makes knowing its maturation process an important step. Thus, the objective of this study was to monitor physicochemical changes in IAC-863 Rangpur lime fruits in order to characterize the physiological maturity of seeds, and to define the ideal harvest point in order to obtain seeds with high physiological quality to obtain rootstocks. Physicochemical analysis of fruits (mass loss, color, soluble solids and acidity) and analysis of seeds (water content, germination and emergence) was performed. Higher germination results were observed in seeds obtained from fruits with higher color index and soluble solids content. The storage of IAC-863 Rangpur lime fruits after harvest increases germination rate, especially in mid-season fruits.
\end{abstract}

Keywords: citrus, germination, rootstock, vigor

\section{Introduction}

The propagation of citrus seedlings is made by the grafting technique, using seeds for the production of rootstocks. In this context, the demand for high quality seeds to obtain these rootstocks is increasing (Zucoloto et al., 2011). Normative Instruction 48 of the Ministry of Agriculture, Livestock and Supply (MAPA) of 24 September 2013 requires that citrus seeds must be analyzed in accordance with the Seed Analysis Rules and may only be marketed with at least $50 \%$ germination.

The harvesting time of fruits for extraction is among factors that influence seed quality; thus, the knowledge of the ripening process, especially with regard to the definition of the ideal harvesting time, seeks to minimize seed deterioration caused by prolonged permanence in the field, and increase the germination rate, since early harvest will lead to the presence of immature seeds (Vidigal et al., 2009; Silip et al., 2010).

In some fleshy fruit species, studies have shown that seeds kept for a certain period of time in the fruit after harvest continue the ripening process and may increase their physiological quality (Pereira et al., 2014). Therefore, post-harvest storage of fruits before seed extraction can be an advantageous aspect, since it allows early harvesting of fruits avoiding risks with possible unfavorable conditions (Castro et al. 2008).

Post-harvest storage of fruits prior to seed extraction also reduces the number of harvests, simultaneously harvesting fruits at various ripening stages, immediately extracting seeds from ripe fruits and submitting the rest to storage. During this period, seeds not yet fully ripe would complete their maturation, while those that were already mature would have their quality preserved by remaining in osmotic equilibrium, i.e., with high degree of humidity (Dias et al., 2006).

IAC-863 Rangpur lime is used as rootstock in most Brazilian citrus orchards. According to the Agricultural Defense Coordination, 4,546,104 Cravo IAC-863 lime seedlings were sold in 2018 in the state of São Paulo, representing $34.3 \%$ of the total rootstock seedlings used. However, there are no studies that have evaluated and correlated fruit characteristics with the physiological quality of seeds and there are no indications of the ideal point for harvesting and extraction. In addition, physicochemical changes that citrus fruits undergo during storage, which may influence seed quality, are not known. Thus, the aim of this work was to monitor the physicochemical alterations in IAC-863 Rangpur lime 
fruits, seeking to characterize the physiological maturity of seeds and to define the ideal point of harvesting fruits for seed extraction.

\section{Material and Methods}

Plant material and experimental design

IAC-863 Rangpur lime fruits (Citrus limonia Osbeck) were harvested from clonal garden plants belonging to the Sylvio Moreira Citriculture Center of the Agronomic Institute (IAC) in Cordeirópolis, state of São Paulo, Brazil, from March to April 2017. Harvesting was performed by visual analysis of fruit coloration in three moments: I 180 days after anthesis (Beginning of season - fruits with green peel); II - 210 days after anthesis (Middle season intermediate color: green/yellow) and III - 240 days after anthesis (End of season - fruits with yellow peel). A total of 420 fruits were harvested per season, immersed in $1 \%$ sodium hypochlorite solution for three minutes and stored in cold chamber $\left(5 \pm 2^{\circ} \mathrm{C}\right.$ and $85 \pm 3 \%$ relative humidity). Evaluations were performed at 0, 15, 30 and 45 days after storage.

The experiment followed a completely randomized design in a $3 \times 4$ factorial scheme, with three harvest moments (180, 210 and 240 days after anthesis), four refrigerated storage times $(0,15,30$ and 45 days) and four replicates of 25 fruits each. At the same time, four replicates with five fruits from each treatment were stored for physicochemical determinations. During storage, evaluations were performed on fruits and seeds.

\section{Assessments}

Mass loss, color and chemical quality of juice

Fruit mass loss was calculated as the difference between initial mass and that obtained at the end of each refrigerated storage time, expressed as percentage, which was determined in 40 fruits, using a digital scale with maximum capacity of 15 kilos.

To determine fruit peel color, Minolta model CR 300 digital colorimeter was used. L (color luminosity), a (green to red color variation) and b values (color variation of blue to yellow) were determined. With $\mathrm{L}$, $a$ and $b$ values, the color index was calculated by the formula $I C=(1000 \times a) /(b \times L)$. This index ranges from approximately -20 to +20 (Hunter color scale). The more negative the $\mathrm{IC}$, the greener the fruit peel color and the more positive, the more orange the fruit peel color. Zero corresponds to yellow color. This measurement was performed in five fruits for each repetition in three points in their equatorial region, and the average for the treatment was calculated.
Soluble solids content was determined by direct reading on B\&S refractometer model RFM 330 and expressed in ${ }^{\circ}$ Brix. The equipment was calibrated with distilled water and then 2 drops of juice (sample) were placed in the optical prism to determine the reading. Data were corrected for temperature and juice acidity.

Acidity was expressed as \% citric acid and determined by volumetric method (AOAC, 2005 ), obtained by titrating $25 \mathrm{ml}$ of juice with $0.3125 \mathrm{~N}$ sodium hydroxide solution using phenolphthalein as indicator. Total soluble solids (TSS) and total titratable acidity (TTA) were used to determine the TSS / TTA ratio, calculating the acidity value of 1 . This ratio indicates the ripening stage of citrus fruits.

\section{Seed water content}

For seed analysis, fruits were divided in half by the equatorial region, with the purpose of manually removing seeds and separating them into normal or aborted. The physiological quality of seeds classified as normal extracted from fruits harvested at different times and stored was evaluated. Seeds were washed with water and neutral detergent at concentration of $10 \%$ to remove the mucilage surrounding fruits and remained drying for two days in the shade until reaching water content equal to $20 \%$ ( \pm 2 ). The moisture content of seeds was determined by the greenhouse method at $105 \pm 3^{\circ} \mathrm{C}$ for a period of 24 hours. Two replicates were used for each sample. The moisture content of a sample is represented by the weight loss of the original sample.

\section{Seed germination and emergence}

Germination test was performed according to criteria established by the Seed Analysis Rules (Brasil, 2009), using as substrate special seed germination paper towel moistened with water volume equivalent to 2.5 times the substrate dry weight. For each replicate, two rolls with 50 seeds were installed, totaling six rolls per treatment, kept in germination at $28^{\circ} \mathrm{C}$. Evaluations were performed on the $30^{\text {th }}$ day after installation, recording the percentage of normal seedlings.

For the greenhouse emergence test, seeds were individually placed in tubes filled with pine bark substrates in $1 \mathrm{~cm}$ deep furrows. Two batches of 50 seeds per seed were sown, totaling 300 seeds per treatment. The substrate was moistened whenever necessary and the final seedling evaluation was performed until emergence stabilization, 60 days after seeding. 


\section{Data analysis}

Evaluation data were submitted to analysis of variance. Averages between harvest times were compared by the Tukey test at $5 \%$ probability. Storage times were analyzed by regression.

\section{Results and Discussion}

Mass loss, color and chemical quality of juice

Mass loss was observed during cold storage of IAC-863 Rangpur lime fruits (Figure 1). However, ripe fruits suffered greater loss compared to other harvest seasons, and mass loss is closely linked to deterioration, rapid respiration rate and development of physiological disorders (Cao et al., 2010). According to Alves et al. (2010), the transpiration process continues after harvest; thus, fruits lose water, decreasing their mass and volume and visual quality. In the case of citrus, this loss comes mainly from the epidermis.

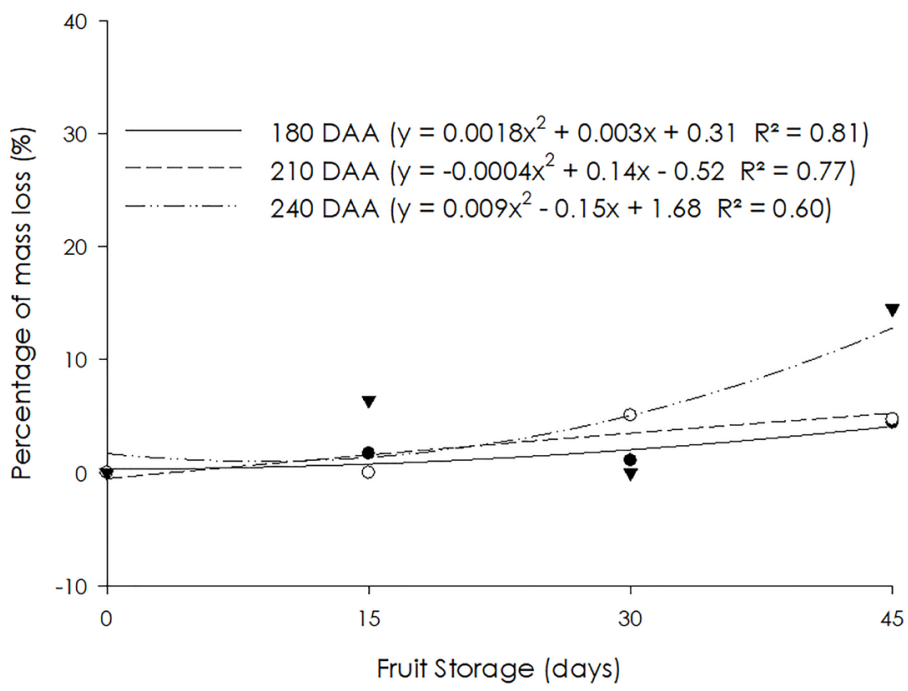

Figure 1. Percentage of mass loss of IAC-863 Rangpur lime fruits harvested at 180, 210 and 240 days after anthesis (DAA) stored in cold chamber for 0,15 , 30, 45 days. (Cordeirópolis, Brazil, 2017).

The peel of fruits harvested 240 days after anthesis that already had yellow color at the beginning of the storage period maintained constant color index. The peel of fruits harvested at 180 and 210 days after anthesis became more yellow during cold storage (Figure 2). According to Alves et al. (2011) and Egea et al. (2010) in the process of fruit ripening, fruit peel color changes due to enzymatic degradation of chlorophyll, which provides green color, and synthesis of carotenoids in the flavedo, turning the fruit color more orange, reddish or yellowish. Cold influences the increase of carotenoid pigments in the fruit peel by the acceleration in chlorophyll reduction, which does not allow obtaining good correlation during ripening.

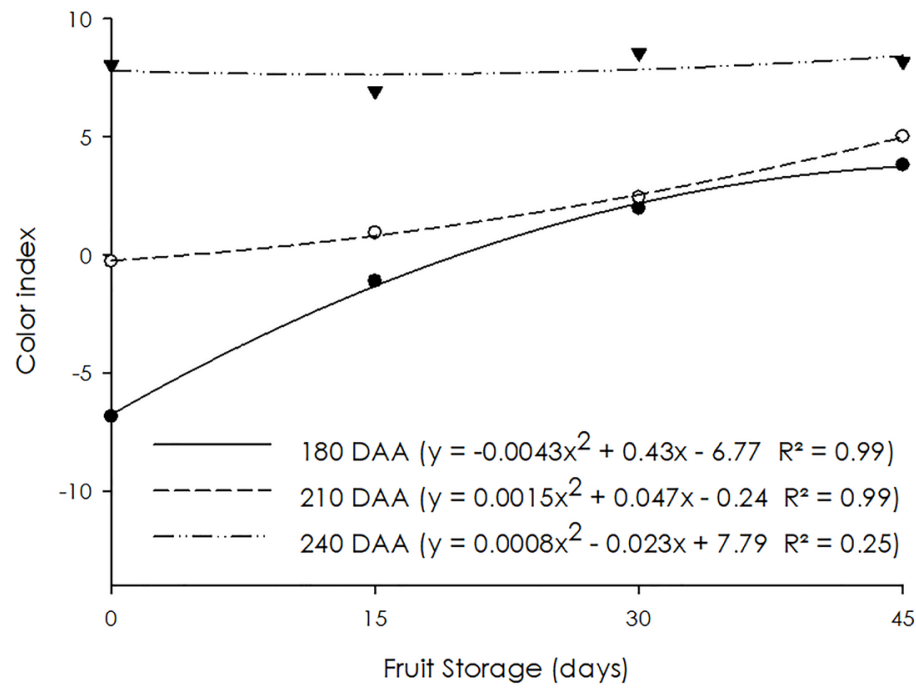

Figure 2. Color index of IAC-863 Rangpur lime fruits harvested at 180, 210 and 240 days after anthesis (DAA) stored in cold chamber for $0,15,30,45$ days. (Cordeirópolis, Brazil, 2017). 
Fruits harvested at 180 and 210 days after anthesis presented increased soluble solids content when stored in cold chamber while fruits harvested at 240 days after anthesis showed decrease in this content (Figure 3).
Fruits with greater degree of maturity from post-harvest respiration may have undergone oxidative processes that may have caused loss of food reserves such as sugars.

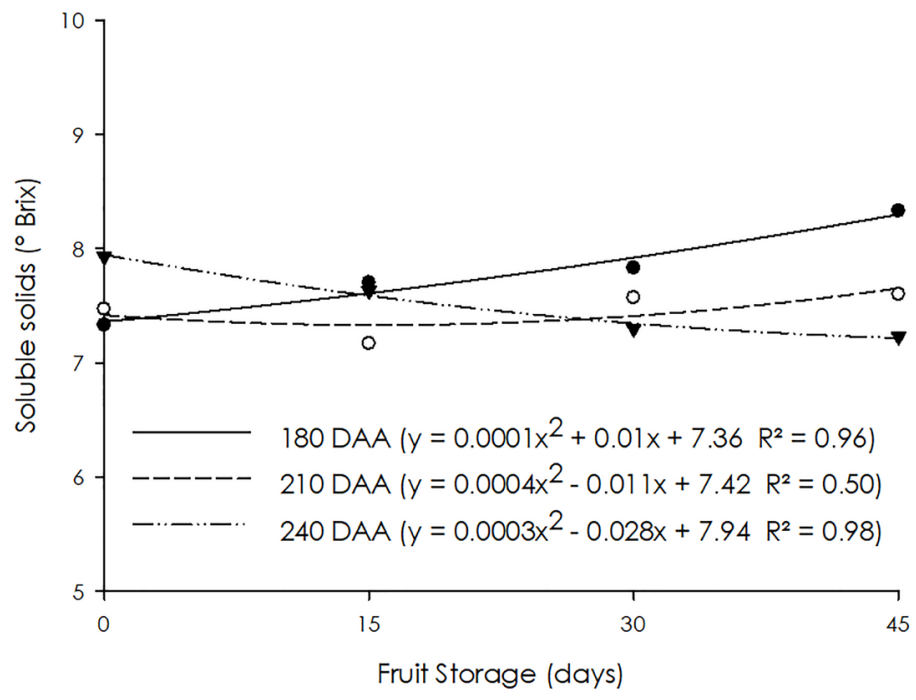

Figure 3. Soluble solids ( ${ }^{\circ}$ Brix) in IAC-863 Rangpur lime juice harvested at 180 210 and 240 days after anthesis (DAA) stored in cold chamber for 0, 15, 30, 45 days. (Cordeirópolis, Brazil, 2017).

The acidity of IAC-863 Rangpur lime fruits is formed in the early stages of growth when acids accumulate and reach their maximum content, which remains constant from that point. The change in acid concentration that occurs during ripening is mainly due to dilution caused by fruit growth (Guardiola, 1999). With cold chamber storage, the acidity of fruits harvested at 210 and 240 days after anthesis remained constant (Figure 4), different from fruits harvested at 180 after anthesis, in which titratable acidity increased, possibly because these fruits did not reach the maximum acid accumulation point before being stored.

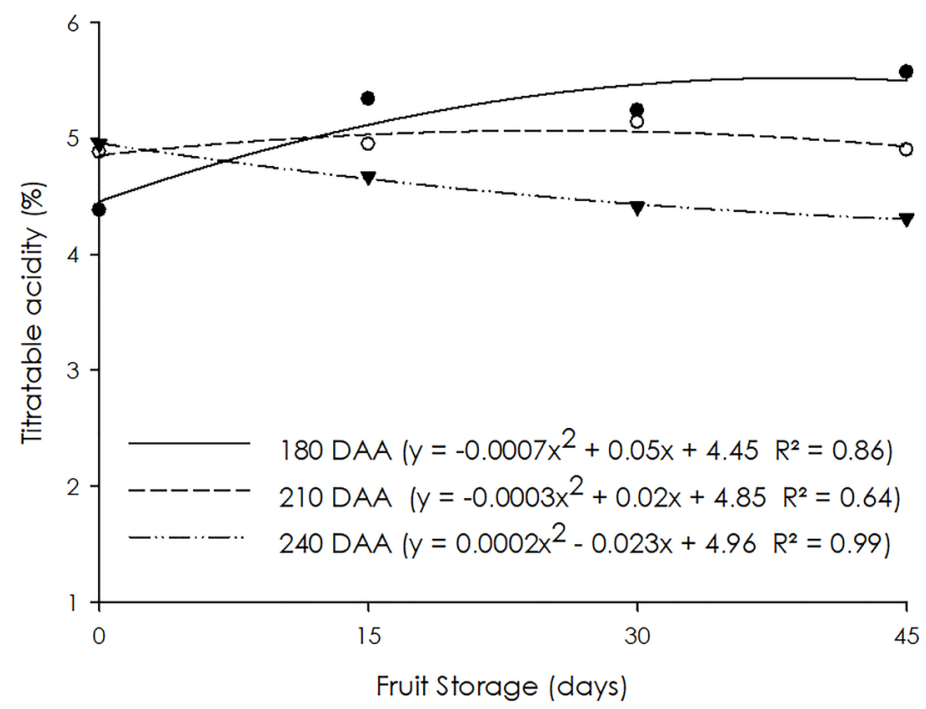

Figure 4. Titratable acidity (\%) of IAC-863 Rangpur lime juice harvested at 180 210 and 240 days after anthesis (DAA) stored in cold chamber for 0, 15, 30, 45 days. (Cordeirópolis, Brazil, 2017).

Fruits harvested 240 days after anthesis, presented higher ratio compared to other treatments (Figure 5). This value is directly related to the ripening stage and stability of the amount of soluble solids among harvesting seasons and the lower acidity of the end-of-season fruits, thus promoting higher ratio. 


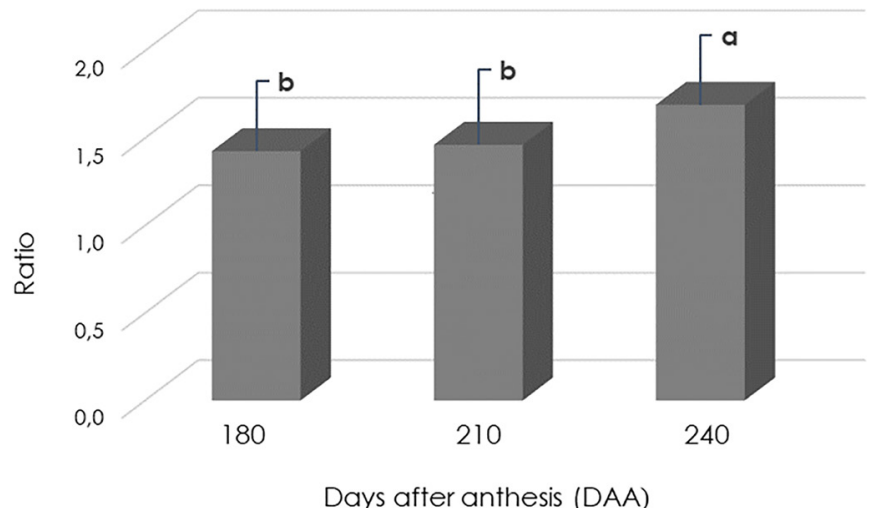

Figure 5. Ratio (soluble solids/titratable acidity) of IAC-863 Rangpur lime juice harvested at 180, 210 and 240 days after anthesis (DAA) stored in cold chamber for $0,15,30,45$ days. (Cordeirópolis, Brazil, 2017). Means followed by the same letter do not differ statistically from each other by the $5 \%$ Tukey test.

During fruit storage, regardless of harvesting season, there were no drastic variations in the chemical composition of fruits (total soluble solids, acidity and ratio) (Figures 3, 4 and 5). The most evident change occurred in peel coloration. According to Medina et al. (2005), in the process of fruit ripening, respiration declines slowly in the later development stages and ethylene evolution is extremely slow during ripening, being therefore classified as fruits with non-climateric behavior.

\section{Seed water content}

At time 0 , the water content of seeds extracted from fruits harvested 240 days after anthesis was lower than seeds extracted from fruits harvested 180 and 210 days after anthesis (Figure 6). In the three harvest seasons, the water content of seeds was between 30 and $45 \%$. According to Carvalho and Nakagawa (2012), recalcitrant seeds reach physiological maturity with water content between 50 and $70 \%$, while in orthodox seeds, maturity occurs in lower water contents, between 30 and $50 \%$, similar to water contents observed for IAC863 Rangpur lime seeds, although these are not classified as orthodox seeds.

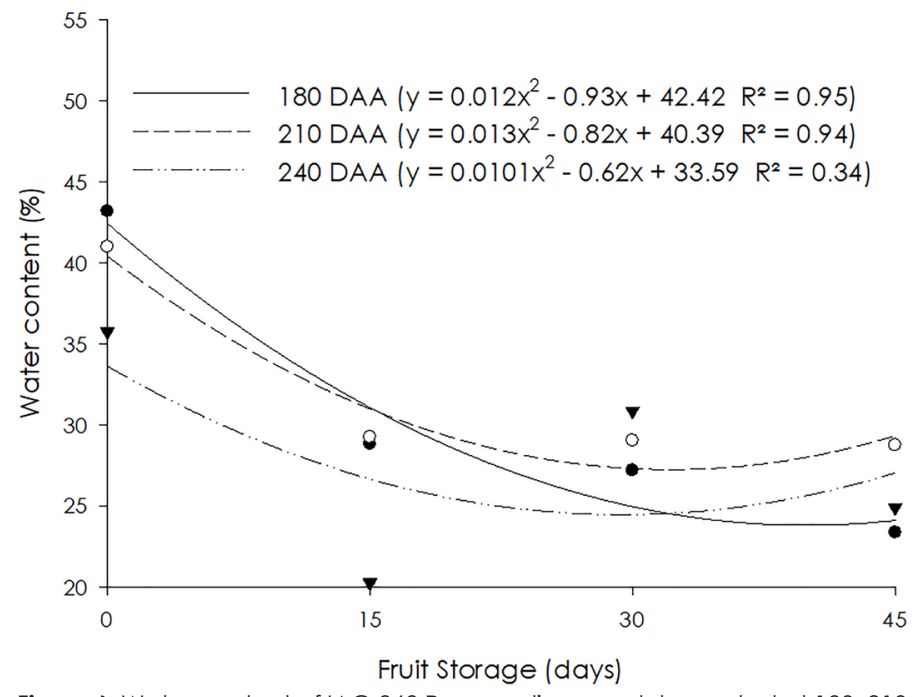

Figure 6. Water content of IAC-863 Rangpur lime seeds harvested at 180, 210 and 240 days after anthesis (DAA) stored in cold chamber for $0,15,30,45$ days. (Cordeirópolis, Brazil, 2017).

Seed germination and emergence

There was an increase in germination percentage

(Figure 7) in seeds extracted from fruits harvest at 180 and 210 days after anthesis during storage. Cold storage of fruits may have broken seed dormancy. According to Struivingi et al. (2013), some varieties of citrus rootstocks have some kind of dormancy, presenting problems of germination uniformity. Dormancy may be caused by seed coat, acting as a physical barrier to water imbibition and gas diffusion, or by the presence of an embryo development inhibitor in the seed coat. Emergence results were stable throughout storage (data not shown). 


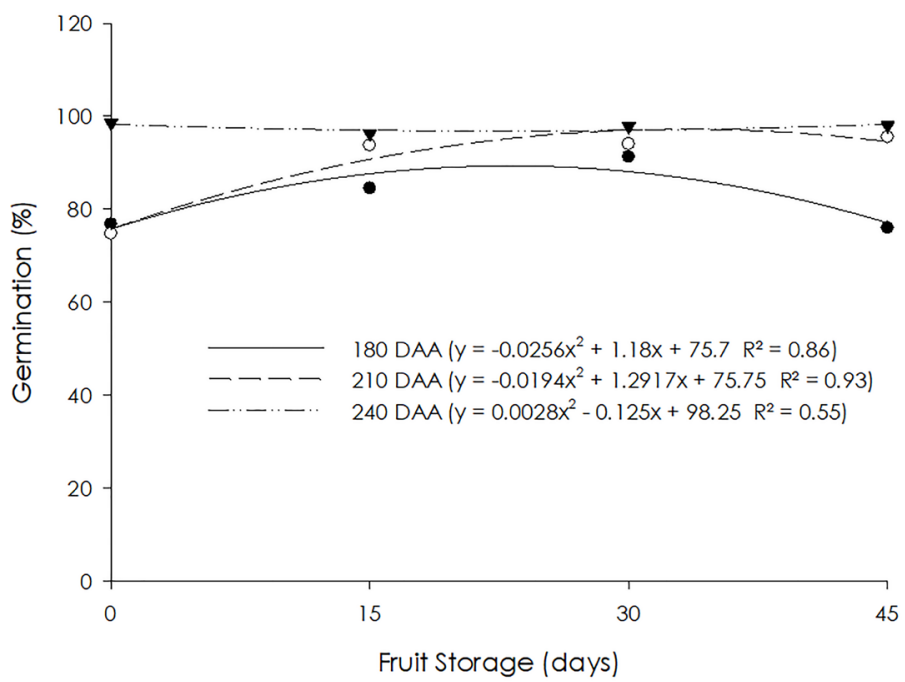

Figure 7. Germination of IAC-863 Rangpur lime seeds harvested at at 180, 210 and 240 days after anthesis (DAA) stored in cold chamber for 0, 15, 30, 45 days. (Cordeirópolis, Brazil, 2017).

Seed germination was positively correlated with acidity and color index of IAC-863 Rangpur lime fruits (Table 1). The process of fruit ripening observed by changes in juice acidity and peel color at different harvest seasons and during fruit storage increased seed germination rate. Thus, these tests may be important as indicative of seed germination response.

Table 1. Simple correlation coefficients $(r)$ between acidity and color index results of IAC-863 Rangpur lime fruits with greenhouse germination determined by the t-test at $5 \%$ probability (Pr).

\begin{tabular}{ccc}
\hline Test & Acidity & Color Index \\
\hline Germination & $0.34^{*}$ & $0.39^{* *}$ \\
\hline$\left({ }^{*}\right)$ significant at 5\% probability, $\left({ }^{* *}\right)$ significant at $1 \%$ probability. &
\end{tabular}

\section{Conclusions}

Higher germination results of IAC-863 Rangpur lime seeds are observed in seeds obtained from fruits with higher color index and soluble solids content (240 days after anthesis: end-of-season fruits - yellow peel).

The storage of IAC-863 Rangpur lime fruits after harvest increases the germination rate, especially in fruits harvested 210 days after anthesis (midle-season -fruits: green/yellow peel).

\section{Acknowledgments}

To FAPESP (process: 2014/16548-8) for the financia support.

\section{References}

Alves, E.D.O., Steffens, C.A., Talamini, A.C.V., Weber, A., Miqueloto, A., \& Brackamann, A. 2010. Armazenamento refrigerado de ameixas' Laetitia'com uso de 1-MCP e indução de perda de massa fresca. Ciência Rural 40: 3036.

Alves, E.D., Maciel, L.P., Pinto, A.S.O., Franco, T.C.M., Bastos, C.T.R.M., Silva, L.H.M. 2011. Avaliação da qualidade nutricional e do teor de polifenóis totais de abacaxi (smooth cayenne) em função da temperatura de armazenamento pós colheita. Revista Brasileira de Pesquisa em Alimentos 2: 128-134.

AOAC. ASSOCIATION OF OFFICIAL ANALYTICAL CHEMISTS. 2005. Official methods of analysis. 18.ed. Arlington.

Brasil. 2009. Ministério da Agricultura, Pecuária e Abastecimento. Regras para análise de sementes. Secretaria Nacional de Defesa Agropecuária, Brasília, Brazil. 399 p.

Cao, S., Hu, Z., Zheng, Y., Lu, B. 2010. Synergistic effect of heat treatment and salicylic acid on alleviating internal browning in cold-stored peach fruit. Postharvest Biology and Technology 58: 93-97.

Castro, M.M., Godoy, A.R., Cardoso, A.I.I. 2008. Qualidade de sementes de quiabeiro em função da idade e do repouso pós-colheita dos frutos. Ciência e Agrotecnologia 32: 1491-1495.

Carvalho, N.M., Nakagawa, J. 2012. Sementes: ciência, tecnologia e produção. 5.ed. FUNEP, Jaboticabal, Brasil. $590 \mathrm{p}$.

Dias, D.C.F.S., Ribeiro, F.P., Dias, L.A.S., Silva, D.H., Vidigal. D.S. 2006. Tomato seed quality in relation to fruit maturation and post-harvest storage. Seed Science and Technology 34: 691-699. 
Egea, I., Barsan, C., Bian, W., Purgatto, E., Latché, A., Chervin, C., Bouzayen, M. Pech, J. C. 2010. Chromoplast Differentiation: current status and perspectives. Plant and

Cell Physiology 51: 1601-1611.

Guardiola, J.L. 1999. Componentes nutritivos de la naranja. In: Naranja y salud. Fundación Valenciana de Estudios Avanzados, Valencia, Espanha. p.143-162.

Medina, C.L., Rena, A.L., Siqueira, D.L., Machado, E.C. 2005. Fisiologia Dos Citros. In: Mattos Junior, D., Negri J.D. Pio M.R., Pompeu Junior, J. Citros. Instituto Agronômico e Fundag, Campinas, Brasil. p. 147-195.

Pereira, F.E.C.B., Torres, S.B., Silva, M.I.L., Grangeiro, L.C., Benedito, C.P. 2014. Qualidade fisiológica de sementes de pimenta em função da idade e do tempo de repouso pós-colheita dos frutos. Revista Ciência Agronômica 45 : 737-744.

Silip, J.J., Tambunan, A.H., Hambali, H., Surahman, M. 2010. Lifecycle duration and maturity heterogeneity of Jatropha curcas Linn. Journal of Sustainable Development 3: 291-295.

Struivingi, T.B., Machado, D.L.M., Santos, D., Siqueira, D.L., Lucena, C.C., Matarazzo, P.H.M. 2013. Qualidade fisiológica de sementes de citros durante 0 armazenamento em ambiente refrigerado. Ciência Rural 43: $1777-1782$.

Vidigal, D.S., Dias, D.C.F.S., Pinho, E.V.R.V., Dias, L.A.S. 2009. Alterações fisiológicas e enzimáticas durante a maturação de sementes de pimenta (Capsicum annuum L.). Revista Brasileira de Sementes 31: 129-136.

Zucoloto, M., Costa, M.G., Carvalho, L.M., Santos, D., Siqueira, D.L. 2011 . Estimativa da produção de sementes de porta-enxertos cítricos por meio da massa de frutos. Revista Ceres 58: 126-128.

Conflict of Interest Statement: The authors declare that the research was conducted in the absence of any commercial or financial relationships that could be construed as a potential conflict of interest.

All the contents of this journal, except where otherwise noted, is licensed under a Creative Commons Attribution License attribuition-type BY. 